Utah State University

DigitalCommons@USU

$1-1-1898$

\title{
LV.- New and Little-Known Hymenoptera taken by Prof. C. H. T. Townsend and Mr. C. M. Barber in New Mexico in 1898.
}

T. D. A. Cockerell

New Mexico Agricultural College

Follow this and additional works at: https://digitalcommons.usu.edu/bee_lab_ca

Part of the Entomology Commons

\section{Recommended Citation}

Cockerell, T. D. A., "LV.- New and Little-Known Hymenoptera taken by Prof. C. H. T. Townsend and Mr. C. M. Barber in New Mexico in 1898." (1898). Ca. Paper 229.

https://digitalcommons.usu.edu/bee_lab_ca/229

This Article is brought to you for free and open access by the Bee Lab at DigitalCommons@USU. It has been accepted for inclusion in $\mathrm{Ca}$ by an authorized administrator of DigitalCommons@USU. For more information, please contact digitalcommons@usu.edu.

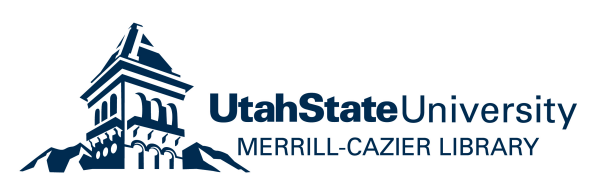


zori. The latter, on account of the better state of its preservation, has been selected as the type.

In the form of its vulva this species approaches both A. rufipalpis (semiannulatus) and A. haploscrpus, and in other features most nearly resembles the latter, but certainly differs in the actual form of the vulva \&c.

\section{EXPLANATION OF PLATE XIII.}

Fig. 1. Eresus inornatus, sp. n. Vulva.

Fig. Araneus streptoceros, sp. n. Vulra.

Fig. 2 a. Ditto. Palpal organ.

Fig. 3. Gasteracantha macrura, sp. n.

4torena nyitice, sp. n. Palpal organ, outer viow.

5. Sparassus croceiceps, sp. n. Vulva.

. Palpal organ from

Fig. 6. Sarotesius below.

Fig. 6 a. Ditto. Tibial spur of palp.

7. Platythomisus pantherinus, sp. $\mathrm{n}$

Fig. 8. Cyrtarachne lactea, sp. n.

9. Araneus pachanus, sp. n. Vulva.

CThis species, based upon a specimen

Fig. 10. Araneus coccinella, Poc. [Th species, based unn. \& Mag. Nat. from Natal, was described by me in the A this opportunity Hist. for September last (p.

LV.-New and little-known Hymenoptera taken by Prof. C. H. T. Townsend and Mr. C. M. Barber in New Mexico in 1898. By T. D. A. Cockerell, Professor of Entomology, New Mexico Agricuttural College.

\section{Andrena Barberi, sp. n.}

9.- Length about 13 millim.

Rather stoutly built, black. Head rather broad, facial quadrangle about square, vertex granulate, front below ocelli strongly longitudinally striate; clypeus minutely tessellate

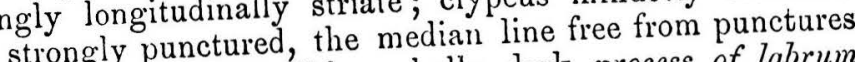
but not smooth; mandibles wholly dark, process of labrum broad and deeply emarginate; antennce wholly black, first joint of flagellum as long as the three following together; face, especially at sides, cheeks, and occiput with fairly abundant greyish-white conspicuously plumose hair, on the vertex more or less blackish. Thorax with greyish-white pubescence, except on the mesothorax and scutellum, where it is sooty; mesothorax dull, minutely tessellate, and with rather large shallow punctures; enclosure of metathorax triangular,

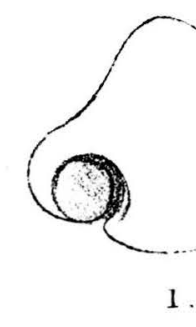


bounded by a raised line, strongly roughened, only feebly plicate at extreme base. Tegulæ picenus, minutely tessellate, with sparse feeble punctures. Wings dusky hyaline, nervures and stigma dark brown; stigma small; submarginal cells large, but the first remarkably short, not longer than the third on the cubital nervure; second little shorter than the first on the cubilal nervure, receiving the first recurrent nervure slightly beyond its middle; third narrowed less than one half to marginal. Legs black, with pale pubescence, that on inner side of first tarsal joints becoming orange. Abdomen minutely tessellate, with only a few minute scattered punctures; hind margins of segments 2 to 4 and extreme lateral margins of 1 with white hair, forming narrow lands; apex with sootcoloured hair.

đ.-Length about 12 millim.; similar to the female, with the usual sexual differences. Clypeus primrose-yellow, with two black spots.

Hab. Ruidoso region, New Mexico. Ruidoso, below Big Rock crossing, about 6600 feet, Aug. 1, 1898, on flowers of Heliopsis scabra (C. H. T. Townsend); South Fork of Eagle Creek, about 8300 feet, Aug. 19, on flowers of Sicyos parviflorus, 1 (Townsend); South Fork of Eagle Creek, about 8100 feet, Aug. 13, on flowers of Rudbeckia laciniata, 3 \& 1 o ('Townsend); Forks of Ruidoso Creek, July 30, 1898 (C. M. Barber).

Easily known by the venation and the colour of the pubescence. Nearest, perhaps, to $A$. helianthi, Rob., which has the small stigma and the same general build and sculpture. On the same day and at the same locality as A. Barberi $\mathrm{Mr}$. Barber took the second known specimen of $A$. apacheorum, Ckll.

\section{Andrena argemonis, Ckll.}

q.-Resembles the male; basal joints of tarsi broader, first four tibiæ black instead of ferruginous; antennæ a trifle shorter; tegulæ larger, base of metathorax smoother; apex of abdomen with very brilliant orange-rufous hair.

Hab. Ruidoso, New Mexico, about 6500 feet, July 25, 1898, on flowers of Erysimum asperum; side cañon north of Ruidoso, about 6800 feet, July 22, on flowers of Verbascum thapsus. Collected by Prof. C. H. 'T. Townsend.

This female differs hardly at all from the description of A. fastuosa, Sm., from Orizaba; but without seeing Smith's types or specimens from the same region it is impossible to say whether the species are identical. 


\section{Halictus aquilce, sp. n.}

9.-Length about 8 millim.

Dark olive-green, with black legs and antennæ, shining, with thin erect, pale yellowish pubescence. Head rather wacial quadrangle broader than long, cheeks unarmed, ocelli prominent and very close together; vertex very densely punctured, as also the front, the face below the antennæ more sparsely punctured; lower half of clypeus purple-black, lower corners of face black; mandibles black, obsuthorax with a scape punctured, flagellum wholly dalpture and rather strong minute lineolate or subtessellate scurongly truncate, the trunbut sparse punctures, metho with ridges, and bounded by a cation rough and sculptured with ounded by a rim, minutely strong rim; base of metathorax bous, the anterior half puncradiately wrinkled; tegula piceous, the anterion nervures and tured; wings hyaline, with a yellown, third submarginal cell stigma a rather dark yellowish marginal; legs quite hairy; narrowed less than half the extreme base, very abdomen dark green, black at the little pubescent, without minutely and not densely punctured, little pubes hair-bands.

Hab. South Fork of Eagle Creek, about 8000 feet, foot of east slope, on foliage, Aug. 21, 1898 (C.H.T. Townsend). II. aquilo is closely related to H. nymphoarum, Rob., of the Eastern States; it is also related to $H$. connexus, Cress., from Texas.

\section{Perdita phacelioe, sp. n.}

o.- Length $3 \frac{1}{2}$ millim.

Head ordinary, face dark bluish green, vertex dark olivegreen; vertex minutely roughened; clypeus rather convex, shiny, with very sparse punctures; a suffused pallid spot near each lower corner of clypeus; mandibles dull yellowish, grooved, tips dark ferruginous ; antenna piceous above, mostly ferruginous beneath; mesothorax minutely granular, with some scattered white hairs, its colour black, shining greenish in certain lights; scutellum and postscutellum black; metathorax dark blue-green, strongly contrasting; the metathorax may be dark blue and the pleura of the same colour; legs black, with white hairs, small joints of tarsi more or less pallid, anterior tibiæ entirely pale in front; tegulæ hyaline, colourless; wings perfectly clear, splendidly iridescent, nervures and margin of the hyaline stigma white; marginal cell squarely truncate, very short, its substigmatal portion almost twice as long as the poststigmatal; second submarginal triangular, distinct; abe apex fringed

Hab. La

at flowers

'T'ownsend.

$P$. phacel known by it. 
triangular, narrowing to a point above; third discoidal distinct; abdomen shining piceous, without bands or spots, apex fringed with white hairs; venter piceous.

Hab. La Cueva, Organ Mountains, N. M., Sept. 2, 1898, at flowers of Phacelia congesta. Collected by C. H. T'. Townsend. Three females.

$P$. phacelice is related to $P$. coneifrons, but will be easily known by its small size and the venation.

\section{Panurginus neomexicanus, sp. $\mathrm{n}$.}

o.--Length about $6 \frac{1}{2}$ millim.

Black, with scanty white pubescence; clypeus and a very small spot on each side of it pale primrose-yellow. Head somewhat broader than long, face little hairy, mandibles black, anterior edge of clypeus black, front and vertex strongly and very densely punctured; antennæ quite long, wholly black, scape punctured ; mesothorax with strong punctures of unequal size, becoming sparse on the shining disk; scutellum with punctures of unequal size; base of metathorax subcancellately wrinkled all over, but the longitudinal wrinkles strongest and most numerous; tegulæ shining, very dark brown; wings rather dusky, nervures and stigma black, first recurrent nervure joining second submarginal cell about the end of its first quarter; legs black, including tarsi, anterior tibia with a short yellow stripe in front; abdomen elongate-cylindrical, sparsely hairy, first segrnent impunctate on disk.

Hab. Top of ridge south of Big Rock, Ruidoso, N. M., about 7400 feet, Aug. 3, 1898, at flowers of Solidago (C. H. T. Townsend).

This is closely allied to P. Bukeri, but is readily distinguished by the small spot on each side of clypeus, black anterior edge of clypeus, and especially the sparsely punctured middle part of mesothorax. From $P$. picipes, Cr., it will be known by the scanty pubescence, lateral face-marks reduced to a spot, mesothorax without a well-impressed central line, black tarsi, \&c. Of the palæarctic species, it seems to come nearest to P. Herzi, Mor., from Eastern Siberia.

\section{Exomalopsis compactulus (Ckll.).}

Anthophorula compactula, Chll. Bull. 24 N. M. Agr. Exp. Sta. (1897) p. 44, ㅇ.

Prof. C. H. 'T. 'Townsend has taken a male and female at La Cueva, Organ Mountains, N. M., on flowers of Phacelia congesta, Sept. 2, 1898. These both have three submarginal 
cells and belong to Exomalopsis; my type of Anthophorula, having but two submarginals, was evidently an aberration, so the latter generic name must fall. It should be added to the original description of the female that the scopa on the posterior tarsi is sooty; the pubescence on the mesothorax and scutellum is fuscous, contrasting with the white pubescence of the hind edge of the prothorax, the pleura, and the base of the metathorax. The margins of the mesothorax have a little very short white hair, conspicuous only in certain lights. The flagellum is a very fine orange-fulvous.

The male is about $5 \frac{1}{2}$ millim. long, with the clypeus; labrum, and mandibles except tips yellow. 'The bright orange flagellum has a black or blackish spot on each joint beneath, that on the last being intensely black and occupying the apical half of the joint. The scape has an orange streak.

The species is, I think, allied to E. pulchella, Cress.

\section{Exomalopsis solidaginis, sp. n.}

o.--Length about 5 millim.

Black, with rather abundant entirely pale pubescence. Head broader than long, vertex quite broad, shining; face densely covered with plumose shining: white hair; clypeus and labrum black; mandibles black, dark rufous at the middle; scape black, flagellum yellowish brown, black above; pubescence of pleura pure white, of thoracic dorsum dirty white; mesothorax smooth and shining, punctured only at the sides; base of metathorax nude, smooth and shining; tegulæ pale testaceous, hairy all over; wings perfectly clear, nervures and stigma very dark brown; second submarginal cell extremely small and narrow, twice as high as long, nurrowest above; transverso-medial nervure joining first aiscoidal cell almost at its extreme base; legs black, with abundant white hair; the tarsi, especially the small joints, ferruginous; hair on inner side of basal joint of hind tarsi fulvous; abdomen short, as usual in the genus, covered with dull white hair, except the disk of the first segment, which is exposed and shining, though not free from hair. Instead of a transverse ridge, with a strongly punctured area behind it, as in E.compactulus $\sigma^{\overrightarrow{ }}$, the first segment has a rounded contour and no conspicuous punctuation.

Hab. Las Cruces, N. M., in the town, on flowers of Solidayo canadensis, subsp. arizonica, Gray, on the bank of the Acequia, Aug. 27, 1898 (C. H. T. Townsend). 


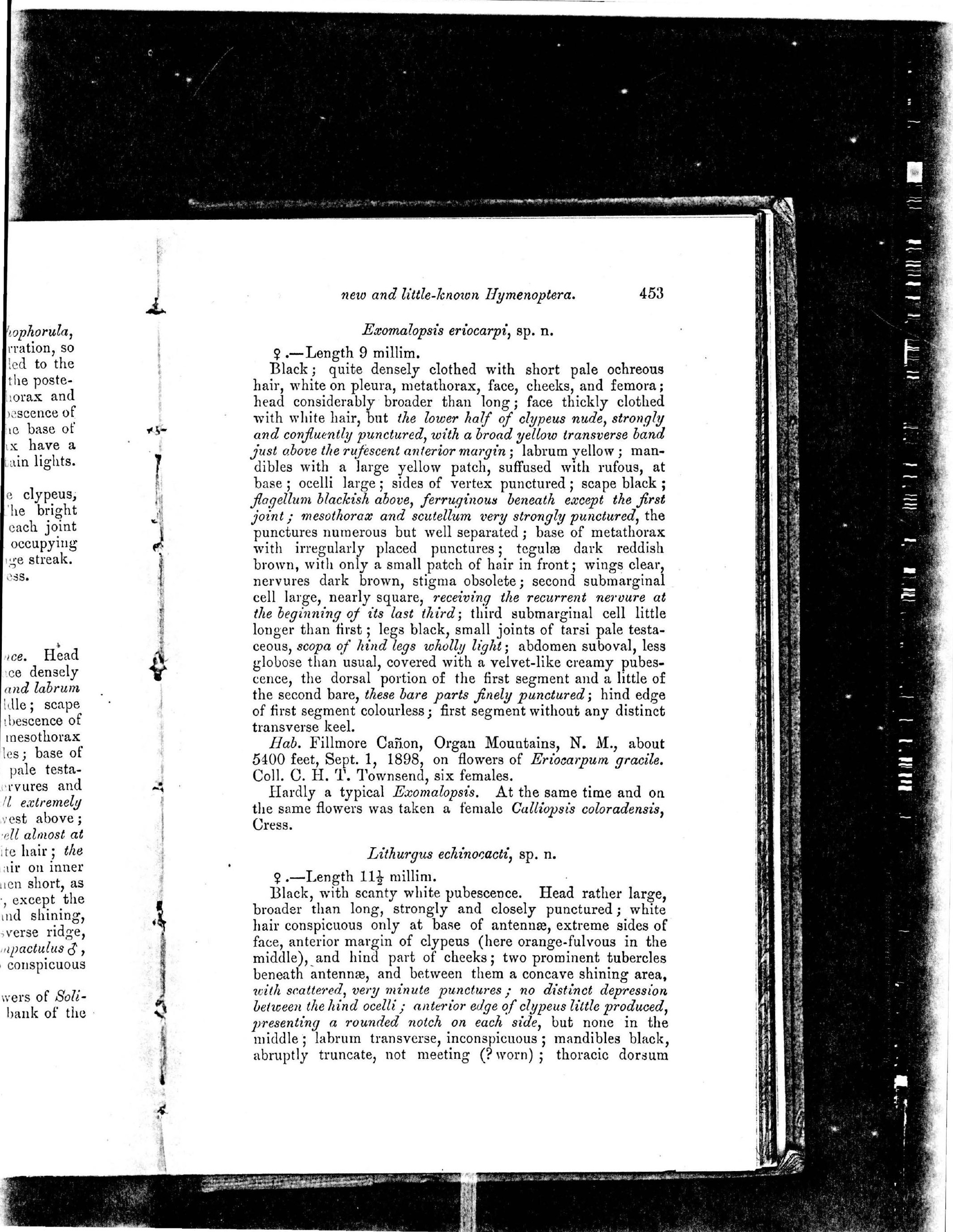


coarsely roughened, nude; hind margin of prothorax marked by a line of snow-white pubescence; base of metathorax dull, hardly sculptured, more or less overlapped by a thin tuft of long hairs springing from just behind it; pleura and sides of metathorax with white hair; tegulæ dark brown, pubescent in front and behind; wings perfectly clear, nervures piceous, a small but distinct stigma; second submarginal cell receiving the first recurrent nervure almost at its extreme base, the second near its end; legs black, with white hair, small joints of tarsi ferruginous, basal joints of tarsi with orange-fulvous hair on inner side; tibiæ conspicuously dentate-tuberculate on the outer side; abdomen shining, sparsely punctured, bare, hind margins of segments with narrow pure white hair-bands; apex with dark purplish-ferruginous hair; ventral scopa white.

Hab. La Cueva, Organ Mountains, N. M., on flowers of Echinocactus Wistizenii, Sept. 4, 1898 (C. H. T. Townsend).

This is clearly distinct from L. apicalis, as determined by Mr. Fox; it also differs from the other described species.

\section{Melissodes crenulaticornis, sp. $\mathrm{n}$.}

5.-Length about 10 millim., antennæ about $8 \frac{1}{2}$ millim.

Black, with dull white pubescence, that on anterior part of mesothorax fulvous, on hind part of mesothorax and scutellum, except the hind border, fuscous, but not mixed at all with black. Head considerably broader than long, facial quadrangle nearly square; clypeus with the upper half black, the lower half primrose-yellow; labrum and mandibles black; antennos wholly black, strongly crenulate, the joints without the longitudinal keels of $M$ ruidosensis; mesothorax with strong but shallow punctures; base of metathorax roughened, with a longitudinal impressed line; tegulæ black, shining, with minute punctures; wings perfectly clear, nervures dark brown, third submarginal cell narrowing more than half to marginal; legs black, with white pubescence, pale orange on inner sides of tarsi; abdomen short and broad, dull and closely punctured; second to sixth segments with broad conspicuous apical white hair-bands; there is no trace of a band on the first segment, except perhaps at the extreme sides, but the segment is quite hairy.

Hab. Prude's Summit, Ruidoso, New Mexico, July 29, 1898 (C. M. Barber).

This is closely related to a male which Mr. Fox has identified as $M$. dentiventris, Sm., but differs from that at once by the black antennæ and dark nervures. It may also be

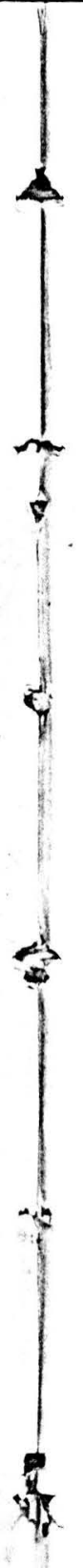

confused black ant flagellicor. half of $\mathrm{tl}$ raised lin black ha From $M$ coloration

M. cre 'Townsen N. M., A Heller, 1 Vicia, $\cdot \mathrm{s}]$ specimen yellow sp

Three, 6500 feet Townsen

\section{$C_{e}$}

$+0 .-1$

Marki versely a large : minal sc: band black, $\mathrm{n}$ with the tibia ye: tarsi yel darker; insect si closely 1 the mes: larger $H$ larly ar: inconspi: Hab. of Cicui 'This ('Trans. 
confused with $M$. perplexa, Cress., but again differs by the black antennæ. It has also some resemblance to Tetralonia flagellicornis, Sm., from Oajaca. From M.ruidosensis, Ckll., common in the same localities, it may be known by the lower half of the clypeus only being yellow, the absence of the two raised lines or keels on the flagellum, and the pale instead of black hair on the abdominal segments above the bands. From $M$. confusa, Cr., it differs constantly in the clypeal coloration at least.

M. crenulaticornis was also collected by Prof. C. H. 'T. Townsend as follows:-Below Big Rock crossing, Ruidoso, N. M., Aug. 21, 1898, on flowers of Geranium atropurpureum, Heller, 1 $\delta$; Big Rock, Ruidoso, July 27, on flowers of Vicia, sp., also July 29, same place and flowers. The specimens from Vicia represent a form maculata, with a small yellow spot on the base of the mandibles.

\section{Crabro Packardii, Cress., 1865.}

Three, one much larger than the others, Ruidoso, N. M., 6500 feet, July 21, on Howers of Cicuta occidentalis (C. H.T. Tuwnsend).

\section{Ceropales fraterna, Sm., subsp. occidentalis, nov.}

o.- Length $5 \frac{1}{2}$ millim.

Markings very bright yellow; scutellum with a transversely diamond-shaped yellow mark; postscutellum with a large nearly semilunar yellow mark; band on first abdominal segment deeply emarginate above, but not interrupted, band on second segment also emarginate above; femora black, rufous, and yellow, anterior femora rufous in front, with the base black and the extreme apex yellow; anterior tibia yellow in front and rufous behind-; first joint of middle tarsi yellow; wings quite dusky, apical margin narrowly darker; abdomen very minutely roughened. Otherwise the insect seems to agree with fraterna. 'The front is extremely closely punctured, with scattered larger shallow punctures; the mesothorax has a similar double punctuation, but the larger punctures are large and deep, numerous, but irregularly arranged. The posterior orbital margins have only an inconspicuous interrupted yellow line.

Hab. Ruidoso, N. M., about 6500 feet, July 21, on flowers of Cicuta occidentalis (C. H.T. Townsend).

'This is probably the western form mentioned by Fox ('Trans. A m. Ent. Soc. 1892, p. 52). 

clear but ly black, st joint, a round ved to a a narrow rt stripe middle firont; a d middle $t$, except ins of the $x$, and the nen, and unctures. æ; first tudinally 6800 feet, C. H. T. possibly nd is pre-

ly 18 , on New to July 19,

om. 1898,

; the hind hite. This the tibiæ, ; the hind black, not and stems

of Mentzelia Rusbyi, Wooton, Aug. 2, 1898, Ruidoso, N. M., one mile above Big Rock, about 6300 feet (C. H. T. Townsend).

This is hardly more than a geographical race of H. McLeayi.

Tenthredo pallicoxa, Provancher, 1878.

One from Ruidoso, N. M., about 8200 feet, foot of divide between Ruidoso and Eagle Creeks, Aug. 12, 1898 (C. H.T. Townsend).

This species has only been recorded from Canada, but the present specimen agrees so closely with the description, that we must assume it to be the same. It is $9 \frac{1}{2}$ millim. long; the hind femora are entirely yellow beneath, the pale markings throughout being a light primrose-yellow. There is a minute light spot above the base of each antenna, and one at the summit of each eye, as in T. nupera, Cress.

\section{Lophyrus Townsendi, sp. n.}

9.-Length $9 \frac{1}{2}$ millim.; width of thorax $4 \frac{1}{2}$ millim.

Antennæ. ferruginous, blackish only at extreme tip, 22 . jointed. Head and thorax ferruginous; face up to level of antennæ almost entirely yellowish; cheeks yellow; middle lobe of mesothorax with a suffused yellow stripe along each lateral margin, and a large black blotch occupying its hind angle; a yellow spot beneath tegulæ; a black patch, on which is a yellowish spot, making a sort of ocellus, on pleura ; a small black spot on each lateral lobe of the mesothorax near its lateral margin; scutellum pale yellow, tipped with ferruginous, its suture with the mesothorax black; legs ferruginous, the anterior knees slightly yellowish; wings hyaline, stained with ferruginous, especially about the marginal cell; abdomen cream-colour, the sutures more or less black, apex dark ferruginous. Head and thorax strongly and rather closely punctured; the large punctures on the vertex have minute ones scattered between them. Claws with a strong denticle on the inner side. Cross-nervure of lanceolate cell oblique, but only moderately so.

Hab. South Fork, Eagle Creek, White Mountains, N. M., about 8000 feet, found dead under a pine-tree, Aug. 17, 1898 (C. H. T. Townsend).

A distinct and interesting species. 